\title{
Daily movement of the sea urchin Strongylocentrotus droebachiensis in different subtidal habitats in eastern Canada
}

\author{
Clément P. Dumont ${ }^{1,3, *}$, John H. Himmelman ${ }^{1}$, Michael P. Russell ${ }^{2}$ \\ ${ }^{1}$ Département de Biologie, Université Laval, Québec City, Québec GIK 7P4, Canada \\ ${ }^{2}$ Biology Department, Villanova University, Villanova, Pennsylvania 19085-1699, USA \\ ${ }^{3}$ Present address: CEAZA, Departamento de Biologia Marina, Universidad Catolica del Norte, Larrondo 1281, Casilla 117, \\ Coquimbo, Chile
}

\begin{abstract}
We measured the movement and orientation of sea urchins at 2 sites in each of 4 habitats on urchin barrens in the northern Gulf of St. Lawrence, eastern Canada. We tagged the urchins measuring 25 to $70 \mathrm{~mm}$ in test diameter using a non-invasive technique involving a knot of fine monofilament thread tied around one spine. Smaller urchins $(<25 \mathrm{~mm})$ were tagged by tightening a loop around the test. Daily displacement increased markedly going from large juveniles (measuring 10-15 $\mathrm{mm}$ in diameter) to small adults $(15-20 \mathrm{~mm})$ and from small adults to large adults (>25-70 mm); however, no effect of size was detectable among large adults measuring from 25 to $70 \mathrm{~mm}$. The increased movement with size was associated with a change in foraging, as gut analysis revealed a marked increase in the proportion of brown algae with increasing size. For large adults, the maximum net distance displaced per day varied among sites from 1.0 to $4.9 \mathrm{~m} \mathrm{~d}^{-1}$, and mean displacement varied from $0.40(\mathrm{SE}=0.07)$ to $1.72(\mathrm{SE}=0.28) \mathrm{m} \mathrm{d}^{-1}$. Distance moved also varied with habitat, and was greater in habitats that were further from kelp beds. Orientation was random and individuals showed frequent reverses in direction from day to day. Hunger state did not affect displacement, as there was no difference in distance moved between starved and fed urchins which were released in the barrens. However, urchins transplanted from kelp beds to the barrens were less active than urchins removed from and returned to the barrens. The shifts in movement with size are probably important in determining the size structure of urchins at different depths. The great distance covered by larger urchins as they move over open surfaces in search of favourable resources probably leads to their increased numbers in shallow habitats where food is abundant.
\end{abstract}

KEY WORDS: Strongylocentrotus droebachiensis · Movement · Foraging activity · Urchin barrens · Tagging Resale or republication not permitted without written consent of the publisher

\section{INTRODUCTION}

Movement patterns can affect spatial distribution of individuals and thus potentially influence population dynamics (Tilman \& Kareiva 1997, Turchin 1998). For example, the abundance of herbivores is influenced by distribution of food resources that likely determine the intensity of grazing and ultimately community structure (Lubchenco \& Gaines 1981, Menge 1995). Therefore, quantifying the movement of individuals can provide insights into patterns of distribution and abundance.

Studies in different geographical areas demonstrate spatial and temporal variation in the abundance and distribution of urchin populations (Chapman 1981, Harrold \& Reed 1985, Andrew 1993, Konar \& Estes 2003). In shallow subtidal habitats, urchins often form destructive grazing fronts at the lower edge of kelp beds, and such aggregations can advance through the kelp beds at a rate of 2 to $4 \mathrm{~m} \mathrm{mo}^{-1}$ (Bernstein et al. 
1983, Scheibling et al. 1999, Gagnon et al. 2004). Destructive grazing leads to the formation of extensive 'urchin barrens' with encrusting coralline algae and isolated patches of less preferred macroalgae which can persist for years to decades (Chapman 1981, Johnson \& Mann 1982). A number of studies show that the boundary between the kelp zone and barrens is determined by physical and biological factors affecting the abundance and foraging behaviour of sea urchins (Bernstein et al. 1983, Keats 1991, Scheibling et al. 1999, Konar \& Estes 2003, Gagnon et al. 2004). However, less is known about the behaviour of urchins in the barrens zone, even though processes in the barrens will likely contribute to the intensity of urchin grazing at the kelp-barrens boundary.

Sea urchins display a wide range of behaviours including chemodetection of food sources (Mann et al. 1984, see Sloan \& Campbell 1982 for review), aggregation (Garnick 1978, Hagen \& Mann 1994, Rodriguez \& Farina 2001), agonistic behaviour (Grünbaum et al. 1978, Tusuchiya \& Nishihira 1985, Shulman 1990), predator avoidance (Jensen 1966, Bernstein et al. 1981, Scheibling \& Hamm 1991, Hagen \& Mann 1992, Hagen et al. 2002), homing (Carpenter 1984, Tuya et al. 2004), and diel (Nelson \& Vance 1979, Tertschnig 1989, Jones \& Andrew 1990, Rogers et al. 1998, Freeman 2003) and seasonal activity rhythms (Agatsuma et al. 2000, Konar 2001). Predation can limit the foraging activity of urchins, for example urchins that feed only at night to avoid visual predators (mainly fish) and return to refuges during the day (Carpenter 1984, Jones \& Andrew 1990). Also, the movement of urchins can be affected by environmental factors such as current velocity and wave action (Lissner 1980, Dance 1987, Tertschnig 1989, Kawamata 1998, Freeman 2003), which can limit urchin grazing (Lissner 1980, Ebeling et al. 1985, Kawamata 1998, Konar 2000). For example, grazing at the lower edges of the kelp beds is reduced in exposed areas because of wave action and the movement of algal fronds (Himmelman 1984, Konar 2000, Konar \& Estes 2003).

Behaviour may also change as individuals increase in size (i.e. ontogenetic change, Werner \& Gilliam 1984). The green sea urchin Strongylocentrotus droebachiensis shows a behavioural shift with increasing size, as juveniles are cryptic, hiding in crevices and under rocks to avoid predators (Keats et al. 1985, Himmelman 1986, Scheibling \& Hamm 1991), whereas upon attaining about $15 \mathrm{~mm}$ in diameter they begin to move on open surfaces to search for food (Himmelman 1986, Raymond \& Scheibling 1987, Dumont et al. 2004a). Displacement distances of several meters a day have been reported for adult $S$. droebachiensis (Garnick 1978, Duggan \& Miller 2001). Mann (1985) used 3 categories to classify the foraging behaviour of green sea urchins, (1) remaining stationary (cryptic) and feeding on detritus supplied by sedimentation and currents, (2) moving in search of food, and (3) forming dense aggregations which slowly advance through algal beds.

Directly observing the displacement of individuals is a powerful approach in elucidating movement patterns within populations (Turchin 1998). However, this is often difficult to achieve because of the lack of appropriate tagging techniques and because following individuals in the field is labour-intensive. Although several workers describe tagging techniques for urchins (see Hagen 1996 and Duggan \& Miller 2001 for review), most are intrusive (e.g. perforation of the test) and thus likely to strongly affect behaviour. We previously evaluated movement of urchins by using fluorescent tagging (calcein) to quantify the dispersion of individuals from release points (Dumont et al. 2004a). This technique demonstrated that juveniles were sedentary and stayed in the same area for prolonged periods, but was less useful for studying the movement of larger urchins (as they all rapidly disappeared from the study sites). Although we clearly demonstrated an increase in displacement with size, the technique did not provide measurements of distance moved per day (Dumont at al. 2004a).

In the present study, we first describe a non-intrusive tagging technique for large urchins (>25 mm) which we used to quantify daily movements of large urchins at numerous sites on urchin barrens. The sites differed in their distance from the kelp zone and in current conditions. We also conducted field manipulations to investigate the influence of the state of hunger on movement. Finally, we modified the tagging technique to quantify daily displacement of large juveniles (10-15 mm) and small adults (15-20 mm).

\section{MATERIALS AND METHODS}

Our study was conducted in the Mingan Islands in the northern Gulf of St. Lawrence, eastern Canada $\left(50^{\circ} 13.6^{\prime} \mathrm{N}, 63^{\circ} 41.12^{\prime} \mathrm{W}\right)$, during the summers of 2001 , 2002 and $2003\left(4\right.$ to $10^{\circ} \mathrm{C}$ during the study periods). The sites were located 1 to $5 \mathrm{~km}$ from each other and selected because of their proximity to the kelp zone, current velocity and type of substratum (Table 1). We selected 2 sites for each of 4 habitats in the barrens zone: (1) Bedrock near kelp, (2) Bedrock with strong current $\left(>0.1 \mathrm{~m} \mathrm{~s}^{-1}\right)$, (3) Bedrock with weak current $\left(<0.1 \mathrm{~m} \mathrm{~s}^{-1}\right)$ and (4) Soft substratum with weak current $\left(<0.1 \mathrm{~m} \mathrm{~s}^{-1}\right)$. The Bedrock near kelp sites were 10 to $15 \mathrm{~m}$ from the kelp bed, the Bedrock with strong and weak current sites were 25 to $50 \mathrm{~m}$ from the kelp bed, and the Soft substratum with weak current sites were 
Table 1. Physical and biological characteristics of the 2 sites studied in each of 4 habitats on barrens in the Mingan Islands, eastern Canada. Mean values are indicated for the current velocity $( \pm \mathrm{SD})$, urchin density $( \pm \mathrm{SE})$, gut $( \pm \mathrm{SE})$ and gonad $( \pm \mathrm{SE})$ mass $($ as a percentage of total mass). Means sharing the same letter are not different (SNK tests, p > 0.05). Agar = Agarum cribrosum, Desm $=$ Desmarestia viridis, Pti $=$ Ptilota serrata

\begin{tabular}{|c|c|c|c|c|c|c|c|c|c|c|c|}
\hline & Date & $\begin{array}{c}\text { Temp. } \\
\left({ }^{\circ} \mathrm{C}\right)\end{array}$ & $\begin{array}{c}\text { Current } \\
\left(\mathrm{m} \mathrm{s}^{-1}\right)\end{array}$ & $\begin{array}{l}\text { Depth } \\
\text { (m) }\end{array}$ & $\begin{array}{c}\text { Dist. from } \\
\text { kelp (m) }\end{array}$ & Substratum & $\begin{array}{c}\text { Erect } \\
\text { macroalgae }\end{array}$ & $\begin{array}{l}\text { Urchin d } \\
15-30 \mathrm{~mm}\end{array}$ & $\begin{array}{l}\text { ensity } \\
>30 \mathrm{~mm}\end{array}$ & $\begin{array}{c}\text { Gut mass } \\
(\%)\end{array}$ & $\begin{array}{c}\text { Gonad mass } \\
(\%)\end{array}$ \\
\hline \multicolumn{12}{|c|}{ Bedrock near the kelp } \\
\hline Marteau & $10 \mathrm{Jul} 02$ & 8.2 & $0.10(0.07)$ & 4 & 15 & Bedrock & None & $55(6)^{\mathrm{d}}$ & $84(5)^{\mathrm{a}}$ & $13.28(1.11)^{\mathrm{c}}$ & $4.15(0.23)^{\mathrm{a}}$ \\
\hline Havre South & $18 \mathrm{Jul} 02$ & 7.8 & $0.09(0.08)$ & 3 & 10 & Bedrock & None & $51(2)^{\mathrm{d}}$ & $78(5)^{\mathrm{a}}$ & $10.51(0.58)^{\mathrm{cd}}$ & $4.18(0.33)^{\mathrm{a}}$ \\
\hline \multicolumn{12}{|c|}{ Bedrock with strong current } \\
\hline Goéland West & 08 Aug 01 & 5.0 & $0.11(0.11)$ & 5 & 30 & Bedrock & Desm & $86(4)^{\mathrm{bc}}$ & $51(4)^{\mathrm{b}}$ & $12.08(1.06)^{\mathrm{cd}}$ & $2.67(0.37)^{\mathrm{bc}}$ \\
\hline Calculot & 24 Jul 02 & 6.2 & $0.14(0.08)$ & 8 & 25 & Bedrock & Agar, Pti & $93(9)^{b c}$ & $32(3)^{\mathrm{c}}$ & $12.97(0.63)^{\mathrm{bc}}$ & $1.41(0.13)^{\mathrm{c}}$ \\
\hline \multicolumn{12}{|c|}{ Bedrock with weak current } \\
\hline Goéland East & 30 Jun 02 & 8.1 & $0.08(0.05)$ & 8 & 30 & Bedrock & Agar & $98(5)^{b}$ & $21(2)^{\mathrm{d}}$ & $15.94(1.28)^{\mathrm{ab}}$ & $3.47(0.39)^{\mathrm{ab}}$ \\
\hline Pointe Enragée & 01 Jul 02 & 7.5 & $0.07(0.04)$ & 6 & 50 & Bedrock, boulders & Agar, Desm & $133(9)^{\mathrm{a}}$ & $19(2)^{\mathrm{d}}$ & $17.52(1.16)^{\mathrm{a}}$ & $1.97(0.28)^{\mathrm{C}}$ \\
\hline \multicolumn{12}{|c|}{ Soft substratum with weak current } \\
\hline Cap du Corbeau & 31 Jul 01 & 4.0 & $0.06(0.04)$ & 10 & 100 & Sand, mud, pebbles & Agar, Desm & $75(6)^{\mathrm{C}}$ & $15(2)^{\mathrm{de}}$ & $12.20(0.89)^{\mathrm{cd}}$ & $1.06(0.28)^{\mathrm{C}}$ \\
\hline Goéland North & 08 Jul 02 & 10.3 & $0.04(0.02)$ & 10 & 80 & Sand, mud, pebbles & Agar & $74(5)^{\mathrm{c}}$ & $11(1)^{\mathrm{f}}$ & $7.55(0.95)^{\mathrm{d}}$ & $1.42(0.06)^{\mathrm{c}}$ \\
\hline
\end{tabular}

80 to $100 \mathrm{~m}$ from the kelp bed (Table 1). The sites for the first 3 habitats were on gently sloped bedrock, mainly covered with encrusting coralline algae, and the deeper soft substratum with weak current sites were on a plateau of pebbles overlying mud and sand. There were patches of the brown macroalgae Agarum cribrosum and Desmarestia viridis at all sites except at the Bedrock near kelp sites. At each site, we recorded current velocity over a tidal cycle on a calm day (using a Vector current meter, Nortek, Norway). We considered a strong current site as a location with a maximum current velocity of $>0.3 \mathrm{~m} \mathrm{~s}^{-1}$ (this velocity would likely limit the movement and feeding activity of urchins, Kawamata 1998). Locations with a maximum current velocity of $<0.3 \mathrm{~m} \mathrm{~s}^{-1}$ were considered as weak current sites. We also sampled 30 randomly placed quadrats $\left(0.25 \mathrm{~m}^{2}\right)$ at each site to quantify the density of urchins in 2 size classes $(15-30$ and $>30 \mathrm{~mm}$; it would have been too laborious to count $<15 \mathrm{~mm}$ urchins that were often cryptic), and collected 10 adult urchins (25-60 mm) between 13 and 25 July 2002 to determine 2 measures of nutritional status, gonad mass and gut mass relative to total wet mass.

We applied ANOVAs to compare urchin densities, and relative gonad and gut masses, among sites, and followed with post hoc tests (Student-Newman-Keuls, SNK) to identify where there were significant differences (Underwood 1997). For these analyses, we evaluated normality using a Kolmogorov-Smirnov test and homogeneity of variances using Cochran's test (Zar 1999).

Adult movement. We tagged adult urchins (>25 mm) in the field without detaching them from the bottom. For each urchin, we first measured its diameter with callipers ( 1 to $2 \mathrm{~mm}$ accuracy) and then tied a monofil- ament thread around one aboral spine with a slipknot (Fig. 1). The thread, with the slipknot and coloured beads ( 1 to 4 ) to identify the urchin, was prepared prior to diving and $1 \mathrm{~cm}$ diameter metal washers were tied to the ends of the thread. The washers allowed us to tighten the slipknot around the spine in the field (we worked with $7 \mathrm{~mm}$ thick diving gloves). The washers and excess thread were cut away once the knot was securely attached. Many threads were prepared and organized on a dispenser prior to diving, and 2 divers could tag about 50 urchins during a 50 min dive. All of the displacement trials with tagged urchins were conducted during calm periods to facilitate the tagging operation and the recording of movements.

We evaluated the effect of the tagging process on the behaviour of the urchin by comparing the displacement of 8 tagged and 8 untagged urchins in a shallow tank $(1.3 \times 1.3 \times 0.1 \mathrm{~m})$ in the laboratory. Digital photos were taken at $1 \mathrm{~min}$ intervals for the first $10 \mathrm{~min}$ and then after $2 \mathrm{~h}$ to record movement. We also quantified the tag retention of large urchins by double tagging 24 individuals in the field ( 1 to 7 urchins at 6 sites).

The position of each tagged urchin was first determined $5 \mathrm{~h}$ after tagging (to be sure there was no effect of tagging, see 'Results'), then at $24 \mathrm{~h}$ intervals for up to $3 \mathrm{~d}$. We did not obtain a daily displacement value for some urchins because they were only observed on the first and third day. The positions were determined by triangulation with respect to 2 fixed bolts separated by $2 \mathrm{~m}$. These spatial coordinates were translated into daily net distance and direction moved. We estimated the error in the triangulation measurements by comparing direct measurements between 2 rocks (simulating the net distance moved for an urchin) with triangulation measurements. The mean difference between 


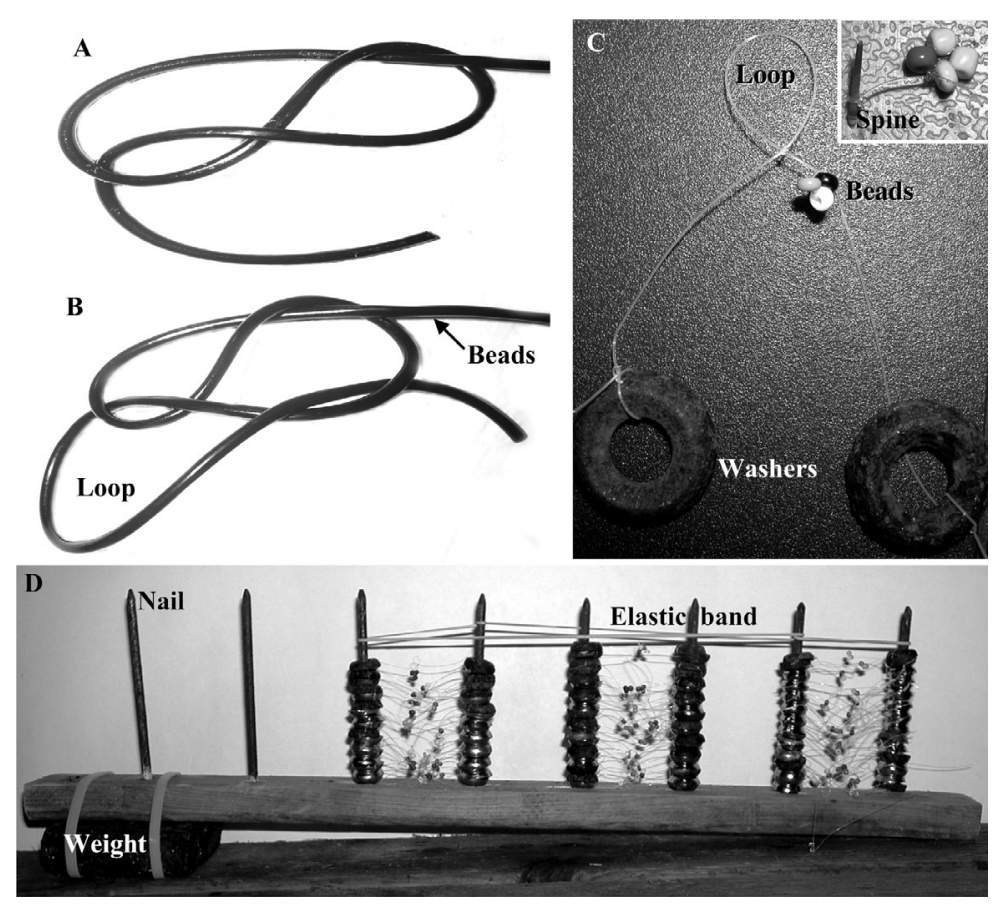

Fig. 1. Urchin tagging method in which coloured beads were attached to one spine with a monofilament line. Tags, the monofilament lines with slipknots $(\mathrm{A}, \mathrm{B})$, colour-coded beads and metal washers attached to the end of the lines (C), were set up on a rack (D) prior to each dive. The washers allowed divers with thick gloves to tighten the knot, and were cut off once the tag was secure on the spine

measured and estimated distances was $3.8 \mathrm{~cm}$ (SD = 20.3, $\mathrm{n}=20$ ), the maximum overestimation was $49.5 \mathrm{~cm}$, this being for an actual distance of $120 \mathrm{~cm}$, and the maximum underestimation was $-55.0 \mathrm{~cm}$, for an actual distance of $219 \mathrm{~cm}$.

Using the above tagging technique, we determined the daily displacement and orientation of tagged adult urchins at 2 sites for each of the 4 habitats on urchin barrens. A 3-way nested ANOVA was applied to test whether movement was influenced by habitat. The factor Site (random factor) was nested within the type of Habitat (fixed factor). Although we measured distance displaced for each urchin on 2 consecutive Days (fixed factor), we kept only one measurement per individual in the analyses so all measurements would be independent (no repeated measures on the same urchin; Underwood 1997). The measurement retained was determined at random. Distances displaced were log-transformed prior to analysis to obtain homogeneity of variance. Tukey tests (with unequal n) were used to identify specific differences within a significant source of variation (Zar 1999). We applied a linear regression to test for correlations between size and distance displaced for large urchins $(>25 \mathrm{~mm}$ ) at each site. To determine if tagged urchins moved in a specific direction (e.g. if they are moving to shallow water where macroalgal food is more abundant), we applied a Raleigh test (Batschelet 1981) for the observations for each day at each site. In this analysis, we excluded urchins with displacements of $<0.5 \mathrm{~m}$, as the Raleigh test only takes direction into account, and we reasoned that urchins that moved so little did not show a specific orientation. We could not compare orientation among sites because of the small values of the mean resultant vector $(R)$ in most of the sites (Chapman 1986). The degree to which urchins changed directions from one day to the next was examined by studying the frequency distribution of turning angles (deviation of the direction from the previous day) for all urchins observed for 2 or 3 consecutive days, and which moved $>0.5 \mathrm{~m}$ each day. In addition, the persistence of directional movement was measured with the mean cosine of the turning angle (Batschelet 1981). Values near one indicate a high degree of directionality and values close to zero indicate that the movement is largely independent of the movement of the previous day.

Effect of hunger on movement. We conducted 2 field manipulations to determine whether state of hunger affected the movement of adult urchins. In the first experiment, we collected 45 urchins from a kelp bed (high food availability) and 45 urchins from an urchin barrens (low food availability), tagged them in a boat, and immediately released 15 individuals of each group into each of 3 sites on urchin barrens. We then recorded the net distance displaced after $24 \mathrm{~h}$. The data were analyzed by applying a 2-way ANOVA, with Origin of urchins (kelp bed or barrens) and Site (3 release sites) as factors.

In the second experiment we compared the movement of urchins (40 to $50 \mathrm{~mm}$ ) that were fed (ad libitum on Alaria esculenta) or starved for $6 \mathrm{wk}$ in the laboratory and then released on urchin barrens. The experimental urchins were collected at Goéland East and each group of 60 urchins (fed and starved) was maintained with a continuous flow of seawater in a $100 \mathrm{l}$ plastic tank. Two cases of cannibalism were observed in the starvation treatment but the remaining urchins appeared in good condition after $6 \mathrm{wk}$. We released 15 tagged urchins from each group at each of 3 sites on the urchin barrens at Goéland East (the sites were separated by 30 to $40 \mathrm{~m}$ ). At the same time, we collected, tagged (on a boat) and returned 15 urchins from each site, to provide a measure of the natural rate of movement at the site. The net distance displaced was measured $24 \mathrm{~h}$ later. On the same day as when we released 
the tagged urchins, 10 of the remaining fed and starved urchins were dissected to determine gut mass relative to total mass. Also, all tagged urchins found $48 \mathrm{~h}$ after the release were collected (each placed in a plastic bag to retain fecal material) and dissected to measure gut mass (gut plus contents). We evaluated the effect of hunger on movement by applying a 2-way ANOVA to distance displaced (log-transformed), with Feeding treatment (fed, starved, field) and Site (3 sites on a barrens) as factors. Also, we compared the conditions of the urchins by applying a 2-way ANOVA to percentage gut mass, with the factors Treatment (fed, starved, field) and Site (3 sites).

Change in movement and diet with urchin size. In addition to measuring adult movement, we also quantified the net displacement of large juveniles $(10-15 \mathrm{~mm})$ and small adults $(15-20 \mathrm{~mm})$ at each of 3 sites, Pointe Enragée, Goéland West and Cap du Corbeau. These smaller urchins were tagged by tightening a monofilament loop (with the same slipknot) around the circumference of the test (the spines were too fragile to support a knot). As tagging could not be done wearing gloves, it was done by briefly (1 to $2 \mathrm{~min}$ ) bringing the urchins to a boat above the study sites. They were returned immediately and we made the first determination of their positions $24 \mathrm{~h}$ later. We compared the distance displaced per day (log-transformed), and also the number of body diameters moved per day, for the 2 size groups by applying 2-way ANOVAs with the random factor Site and the fixed factor Size. We did not include our movement data for large urchins in the same analysis because of the different technique used to tag large urchins (a knot tied to one spine).

We evaluated changes in diet with size by quantifying the proportion of different foods in the guts of 3 size groups, 10-15, 15-20 and 25-70 mm (10 urchins per group), at each of 2 sites, Pointe Enragée and Goéland West. For each urchin, we placed the entire intestinal tract in seawater and teased apart the contents. Then we determined the food items found under 100 randomly selected points in a digital photograph of the gut contents. We compared the percentage of brown algae in the gut contents by applying a 2-way ANOVA to percentage brown algae (arcsine transformed), with the fixed factor Size (10-15, 15-20, 30-70) and the random factor Site (Pointe Enragée and Goéland West).

\section{RESULTS}

The Bedrock near kelp sites (10-15 m from the Alaria fringe) had the highest densities of large urchins (>30 mm) and their numbers showed a general decrease with distance from the kelp zone (ANOVA,
$F_{7,241}=85.37, \mathrm{p}<0.001$, SNK tests, Table 1$)$. In contrast, small urchins $(15-30 \mathrm{~mm})$ were found in the highest densities at the deeper sites, furthest from the kelp zone (ANOVA, $F_{7,241}=17.73, \mathrm{p}<0.001$, SNK tests, Table 1). Although gut fullness (gut mass to total mass) varied among sites (ANOVA, $F_{7,64}=8.89$, p $<0.001$, Table 1), it did not seem to vary with distance from the kelp zone. In contrast, gonad mass (relative to total mass) decreased with distance from the kelp zone (ANOVA, $F_{7,64}=11.36, \mathrm{p}<0.001$, SNK tests, Table 1). Urchins at the Bedrock near kelp sites had the largest gonads and those at the Soft substratum with weak current sites the smallest. The large size of the gonads and guts at Goéland East may have been because drift algae were more abundant at this site.

\section{Adult movement}

A total of 382 large adult urchins $(25-70 \mathrm{~mm})$ were tagged without removing them from the bottom in the field (a knot tightened around one spine) and for 244 individuals subsequent positions were recorded at least once. We recaptured 23 of the 24 double-tagged urchins after $24 \mathrm{~h}$, and $62.5 \%$ had retained both tags. In the laboratory we observed that tying a monofilament thread (with beads) to a spine increased the movement of the spine during a few minutes; however, the distance displaced after $2 \mathrm{~h}$ was similar for tagged and untagged urchins $\left(2.95 \mathrm{~cm} \mathrm{~min}^{-1}, \mathrm{SE}=0.38\right.$, versus $2.62 \mathrm{~cm} \mathrm{~min}^{-1}, \mathrm{SE}=0.59 ; t$-test $, t_{14}=0.69, \mathrm{p}=0.50$, $\mathrm{n}=8)$.

Mean net distance displaced by tagged adult urchins on the barrens varied among sites from $0.40(\mathrm{SE}=0.07)$ to $1.72(\mathrm{SE}=0.28) \mathrm{m} \mathrm{d}^{-1}$ and the maximum values varied from 1.1 to $4.9 \mathrm{~m} \mathrm{~d}^{-1}$ (Fig. 2). Distances displaced varied among habitats but not between sites of the same habitat or between days at the same site (Table 2). The mean displacement in the Bedrock near kelp habitat was lower than in the 3 others habitats (Table 2, Tukey test, $\mathrm{p}<0.05$ ) where $51.8 \%$ of the individuals moved $<0.5 \mathrm{~m}$ (Fig. 2). Mean displacement on the Soft substratum with weak current habitat was more than twice that in the Bedrock near the kelp habitat (Fig. 2). The urchins on Soft substratum with weak current tended to move further than those on Bedrock with either strong or weak current but the differences were not significant (Fig. 2).

We found no evidence of directional movement. Our analyses, applied to urchins that moved $>0.5 \mathrm{~m}$ in a day ( 40 to $88 \%$ of the urchins depending on the site), showed that orientation was random on all days and sites, except for the second day at the Goéland North site ( $R=0.55, p=0.045$; Fig. 3). The distribution of the turning angles (again for urchins that moved $>0.5 \mathrm{~m}$ 


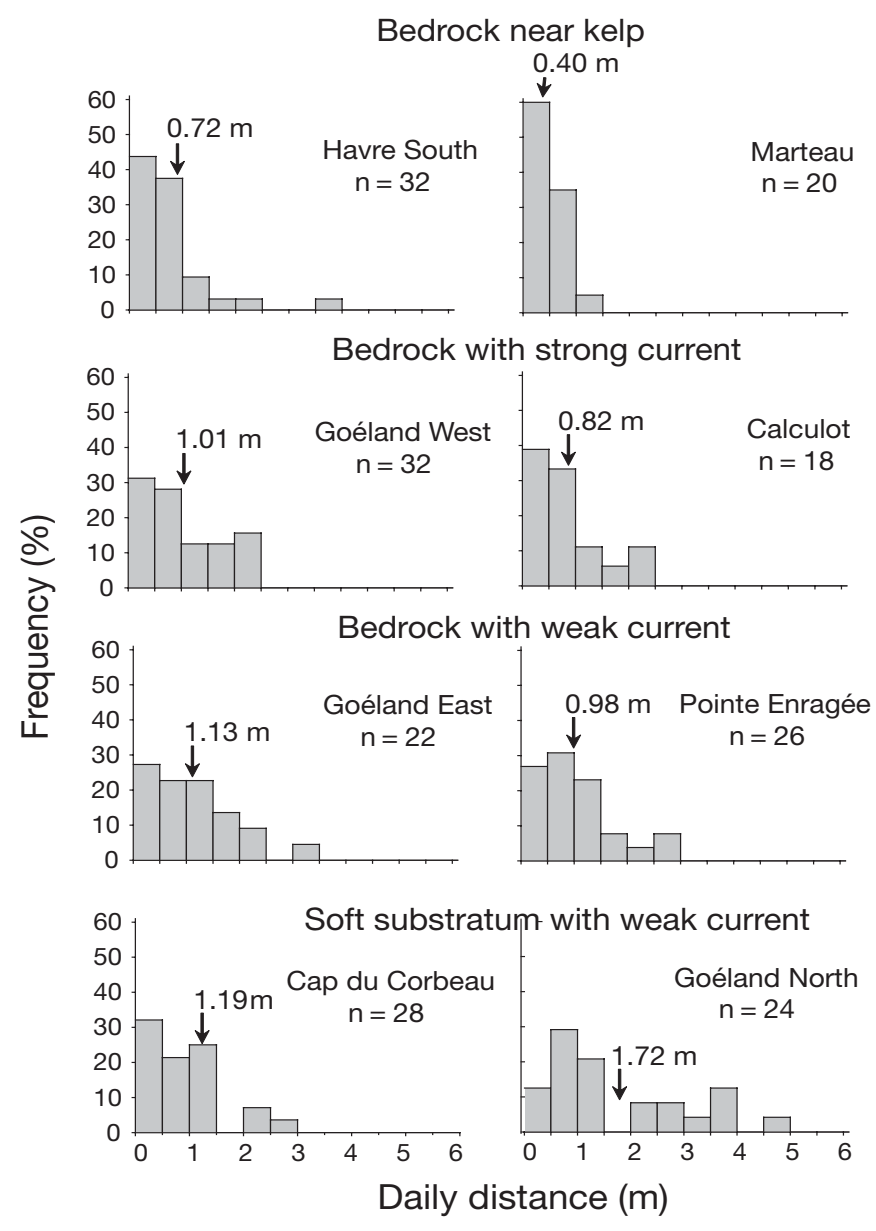

Fig. 2. Strongylocentrotus droebachiensis. Net distance displaced by adult sea urchins $(25-70 \mathrm{~mm})$ tagged in 4 different habitats on urchin barrens ( 2 sites per habitat). Arrows indicate mean distance displaced

$\mathrm{d}^{-1}$ ) indicated that $59 \%$ of individuals changed their direction from one day to the next by $>90^{\circ}$ (Fig. 4). Frequent reversals in direction were also indicated by a negative mean cosine of the turning angle $(-0.22 \pm$ $0.09, \mathrm{n}=62$ ). This low value means that the direction of the daily displacement from one day to the next was largely independent.

Table 2. Results of a 3-way nested ANOVA applied to daily net distance displaced by tagged adult urchins $(25-70 \mathrm{~mm})$ at 2 sites in each of 4 habitats on urchin barrens

\begin{tabular}{|lcrcc|}
\hline Source of variation & df & MS & $F$ & $\mathrm{p}$ \\
\hline Habitat & 3 & 10.14 & 8.04 & 0.04 \\
Site (Habitat) & 4 & 1.26 & 0.89 & 0.54 \\
Day & 1 & 2.18 & 1.54 & 0.28 \\
Habitat $\times$ Day & 3 & 0.98 & 0.69 & 0.60 \\
Site (Habitat) $\times$ Day & 4 & 1.42 & 1.51 & 0.20 \\
Residual & 186 & 0.94 & & \\
\hline
\end{tabular}
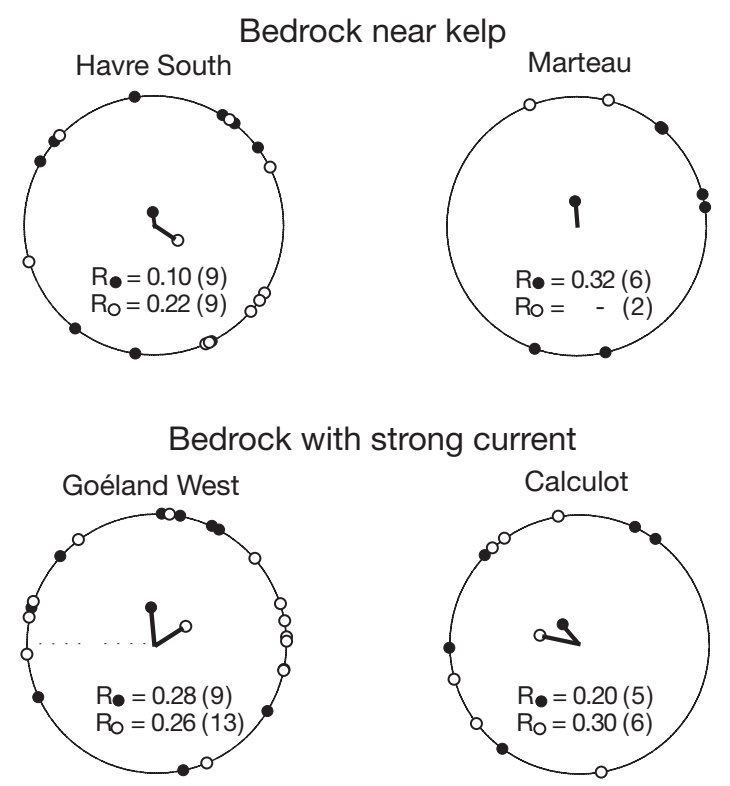

Bedrock with weak current
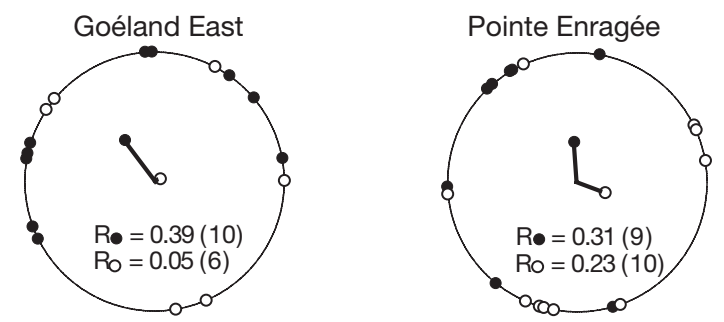

Soft substratum with weak current
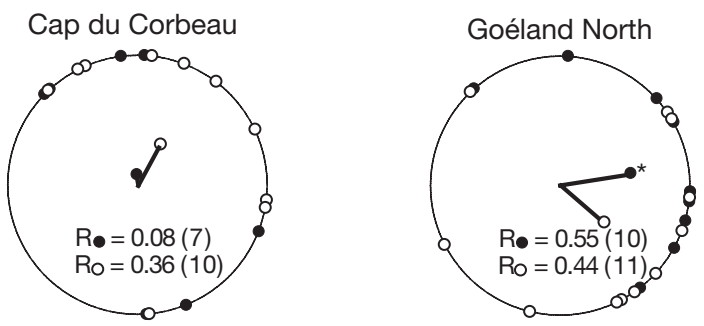

Fig. 3. Strongylocentrotus droebachiensis. Polar directions moved by sea urchins during the first $(\mathbf{O})$ and second $(\mathbf{0})$ day in each of the 2 sites for 4 habitats on urchin barrens. Arrows ending in an open or dark circle represent the resultant vectors for Day 1 and Day 2, respectively. The resultant vector (R) of the Raleigh's test is indicated for each site. * indicates a significant direction (Raleigh tests, $\mathrm{p}<0.05$ ), and the number of urchins followed at each site (excluding individuals that moved $<0.5 \mathrm{~m} \mathrm{~d}^{-1}$ ) is indicated in parentheses

Linear regression analyses showed no correlation between distance displaced and urchin size, for the adults measuring 25 to $70 \mathrm{~mm}$ in diameter, at any site, although there was a low $p$-value $(p=0.09)$ at the Cap du Corbeau site where urchins were smaller than at the other sites (Fig. 5). 


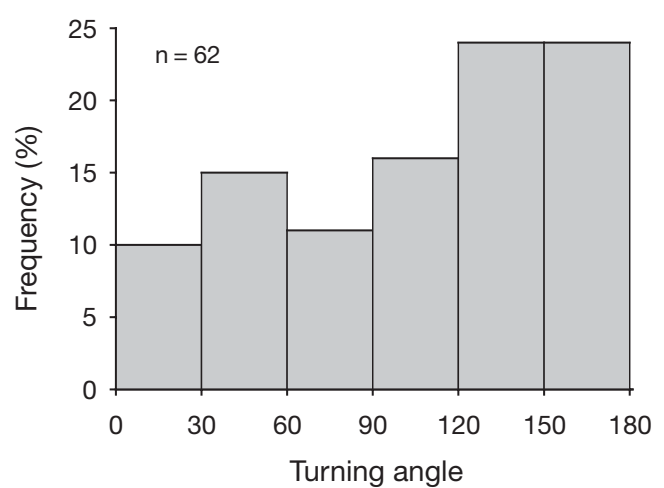

Fig. 4. Strongylocentrotus droebachiensis. Frequency distribution of turning angles for sea urchins observed over 2 successive days (excluding urchins that moved $<0.5 \mathrm{~m} \mathrm{~d}^{-1}$ )

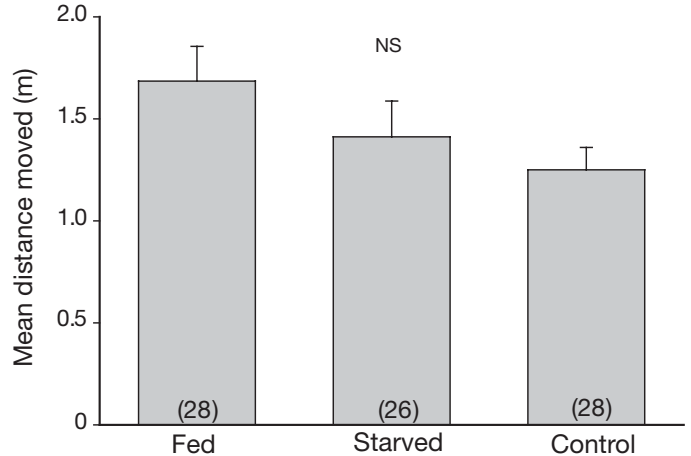

Fig. 6. Strongylocentrotus droebachiensis. Net distance displaced by sea urchins that were fed or starved in the laboratory for $6 \mathrm{wk}$ and then released at 3 sites on barrens. Control shows distance displaced by urchins that had not been removed from the barrens. Number of urchins examined is indicated in parentheses and vertical bars represent SE
Bedrock near kelp

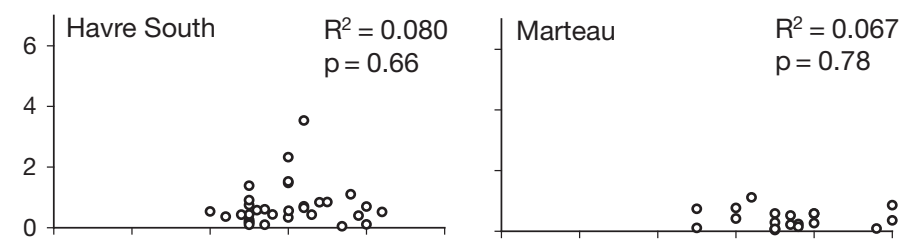

Bedrock with strong current

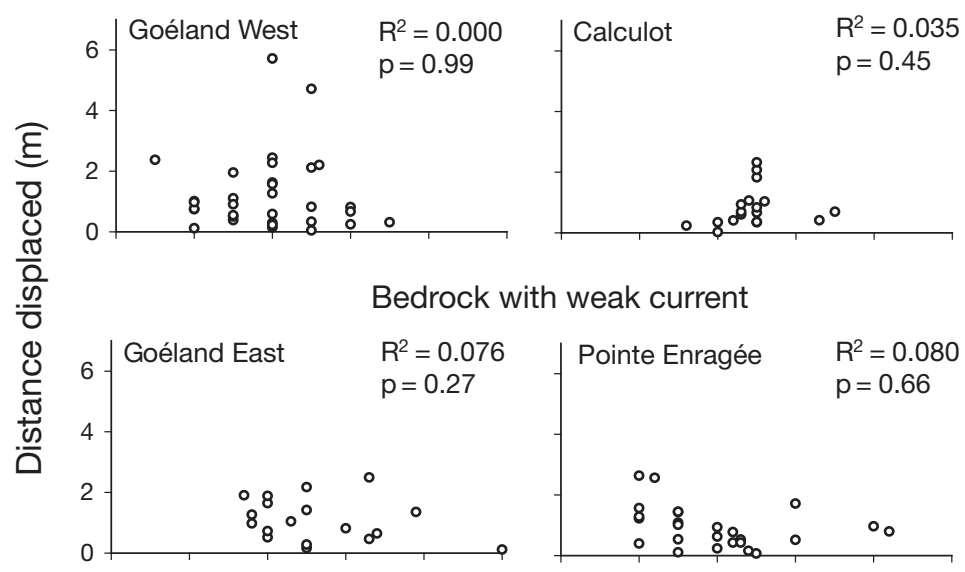

Soft substratum with weak current

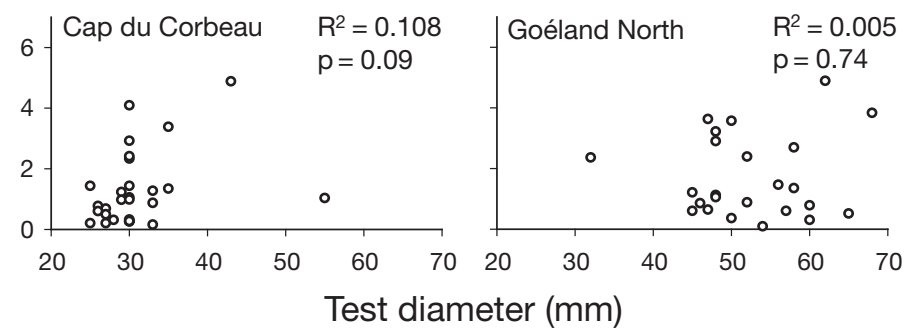

Fig. 5. Strongylocentrotus droebachiensis. Relation of net distance displaced to test diameter for tagged sea urchins at 8 sites representing 4 types of habitats on urchin barrens. Coefficient of regression $\left(\mathrm{R}^{2}\right)$ and $\mathrm{p}$-value are indicated for each site

\section{Effect of hunger on movement}

The net distance displaced by urchins transplanted from the kelp zone (where food was abundant) to the barrens was less than for urchins removed from barrens (low food abundance) and returned to the barrens (ANOVA, $\left.F_{1,58}=5.32, \mathrm{p}=0.025\right)$ with values of $1.42(\mathrm{SE}=$ $0.22)$ and $2.12(0.23) \mathrm{m} \mathrm{d}^{-1}$, respectively. The factor Site $\left(F_{2,58}=1.99, \mathrm{p}=0.15\right)$ and the interaction $\left(F_{2,58}=0.50, \mathrm{p}=0.61\right)$ were not significant.

Net distance displaced was similar for urchins that were either fed or starved for 6 wk in the laboratory before being returned to the barrens for measurements of displacement (ANOVA, Treatment effect, $F_{2,73}=1.53, \mathrm{p}=0.22$; Site effect, $F_{2,73}=1.90, \mathrm{p}=0.16$; Interaction, $F_{4,73}=$ $0.55, p=0.70$, Fig. 6). The starved urchins had nearly empty guts and the fed urchins full guts after the $6 \mathrm{wk}$ feeding regimes in the laboratory ( $t$-test, $t_{18}=11.41, \mathrm{p}<0.001$, Fig. 7). However, gut fullness of both groups converged in $48 \mathrm{~h}$ on the barrens to an intermediate level similar to the control group (ANOVA, Treatment effect, $F_{2,49}=2.89, \mathrm{p}=0.06$; Site effect, $F_{2,49}=2.74, \mathrm{p}=$ 0.07 ; Interaction, $F_{4,49}=2.13, \mathrm{p}=0.09$ ).

\section{Change in movement and diet with urchin size}

The displacement of large juvenile urchins (10-15 mm) tagged with a monofilament loop around the test was only half that of small adult urchins $(15-20 \mathrm{~mm})$ tagged in the same way 


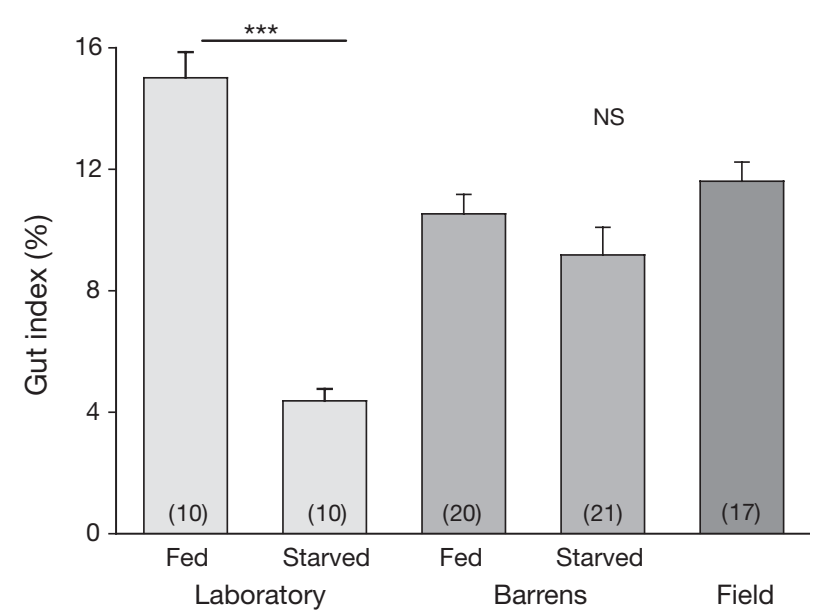

Fig. 7. Strongylocentrotus droebachiensis. Gut mass as a percentage of total mass (+SE) for sea urchins that had been fedor starved in the laboratory for 6 wk (Laboratory), for urchins from the fed and starved groups that had been released on the barrens for $48 \mathrm{~h}$ (at 3 sites) (Barrens), and for urchins that were collected from the barrens (Field). ${ }^{* * *}$ indicates a significant difference $(p<0.001)$. NS indicates columns are not significantly different ( $p>0.05)$. Number of urchins examined is indicated in parentheses and vertical bars represent SE

(Table 3, Fig. 8). Although not strictly comparable, because of the different tagging technique, the displacement distances observed for these large juveniles $(10-15 \mathrm{~mm})$ and small adults $(15-20 \mathrm{~mm})$ were much less than for large adults $(25-70 \mathrm{~mm})$ tagged by tying beads to a single spine ( 4 times less for large juveniles and 2.5 times less than small adults) (Fig. 8). The mean number per of body diameters moved day increased by $36 \%$ between large juveniles $(10-15 \mathrm{~mm})$ and small adults $(15-20 \mathrm{~mm})$ but the difference was not significant (ANOVA, Size effect, $F_{1,78}=1.82, \mathrm{p}=0.24$; Site (Size) effect, $F_{4,78}=1.20, \mathrm{p}=0.32$ ), and the moves per day for large adults $(25-70 \mathrm{~mm})$ were similar to those of small adults (Fig. 9). In contrast, the maximum number of body diameters moved per day increased markedly with size, as it was 69 for large juveniles, 122 for small adults and 220 for large adults. Although we could not double tag small urchins, we noted that the

Table 3. Results of a 2-way ANOVA comparing the daily net distance displaced by tagged large juvenile (10-15) and small adult (15-20 mm) urchins on the barrens

\begin{tabular}{|lrrrr|}
\hline Source of variation & df & \multicolumn{1}{c}{ MS } & \multicolumn{1}{c}{$F$} & \multicolumn{1}{c|}{$\mathrm{p}$} \\
\hline Site & 2 & 1.07 & 1.19 & 0.31 \\
Size & 1 & 11.01 & 12.21 & 0.0007 \\
Site $\times$ Size & 2 & 0.33 & 0.36 & 0.70 \\
Residual & 78 & 0.90 & & \\
\hline
\end{tabular}

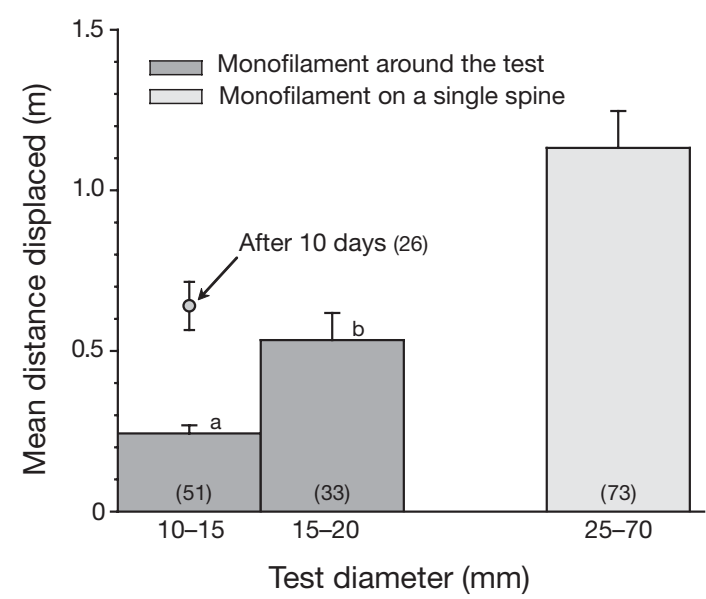

Fig. 8. Strongylocentrotus droebachiensis. Distance displaced for large juvenile $(10-15 \mathrm{~mm})$ and small adult $(15-20 \mathrm{~mm})$ urchins, both tagged with a monofilament thread tied around the circumference of the test, and for large adults $(25-70 \mathrm{~mm})$ tagged with a thread tied to a single spine. The values were obtained from tagging of the 3 size groups at Cap du Corbeau, Pointe Enragée and Goéland East. Columns sharing the same letter are not significantly different $(p<0.05)$. Numbers of urchins for which we had recorded displacement distance are shown in parentheses. Point represents the mean displacement of large juveniles after $10 \mathrm{~d}$. Vertical bars represent SE

tag loss was less for small juveniles ( $45 \%$ of large juveniles tagged were found the next day, and $60 \%$ of these were found again after $10 \mathrm{~d}$ ) than small adults ( $40 \%$ of small adults tagged were found the next day and only $20 \%$ were found after $2 \mathrm{~d}$ ).

We also observed a change in diet with increasing size (Fig. 10). Brown algae made up $52 \%$ of the gut contents for 10-15 mm urchins at Pointe Enragée and $60 \%$ for those at Goéland East. The percentage signif-

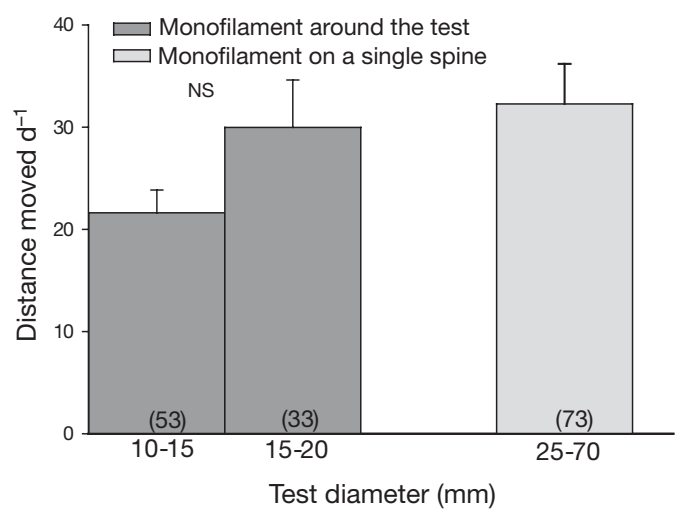

Fig. 9. Strongylocentrotus droebachiensis. Number of body diameters moved $\mathrm{d}^{-1}$. Groups as defined in Fig. 8. The values were obtained from tagging of the 3 size groups at Cap du Corbeau, Pointe Enragée and Goéland East. NS indicates columns are not significantly different. Numbers of urchins tagged are shown in parentheses and vertical bars represent +SE 
icantly increased with urchin size and attained 89 and $95 \%$, respectively, for 30-70 mm urchins (ANOVA, Size effect, $F_{2,72}=109.83, \mathrm{p}=0.01$; Site effect, $F_{1,72}=$ 1.47, $\mathrm{p}=0.33$; Interaction, $\left.F_{2,72}=0.15, \mathrm{p}=0.86\right)$. Most of the remaining materials in the guts (coralline algae, sediment, and red algae) became less abundant with increasing urchin size. One adult from Goéland East contained urchin remains (spines and test) enveloped in mucus, suggesting cannibalism or scavenging.

\section{DISCUSSION}

Our new marking technique for sea urchins, in which a tag was attached to the spine of an urchin without removing it from the bottom, is suitable for short-term (1 to $3 \mathrm{~d}$ ) studies of movement in the field. Failure to recover a tagged individual was primarily because the urchin dropped the tagged spine (possibly a stress response) as $95.8 \%$ of double tagged urchins were recovered after $24 \mathrm{~h}$ (and $37.5 \%$ had lost one tag). A few individuals could have fallen victim to predation or simply were not been found.

Our observations of tagged large adult urchins (25-70 $\mathrm{mm}$ in diameter) on barrens showed increased movement of urchins with increased distance from the kelp zone. Urchins were relatively sedentary near kelp beds ( $88.1 \%$ of individuals moving $<1 \mathrm{~m} \mathrm{~d}^{-1}$ ), whereas $52.4 \%$ of urchins on barrens in deeper water, under weak current conditions, moved $>1 \mathrm{~m} \mathrm{~d}^{-1}$. Similar results are reported for others echinoids (Table 4). For example, Mattisson et al. (1977) observed that Strongylocentrotus franciscanus moved $0.08 \mathrm{~m} \mathrm{~d}^{-1}$ inside a kelp bed compared to $0.54 \mathrm{~m} \mathrm{~d}^{-1}$ at $100 \mathrm{~m}$ from the kelp bed. The rate of movement of Evechinus chloroti-

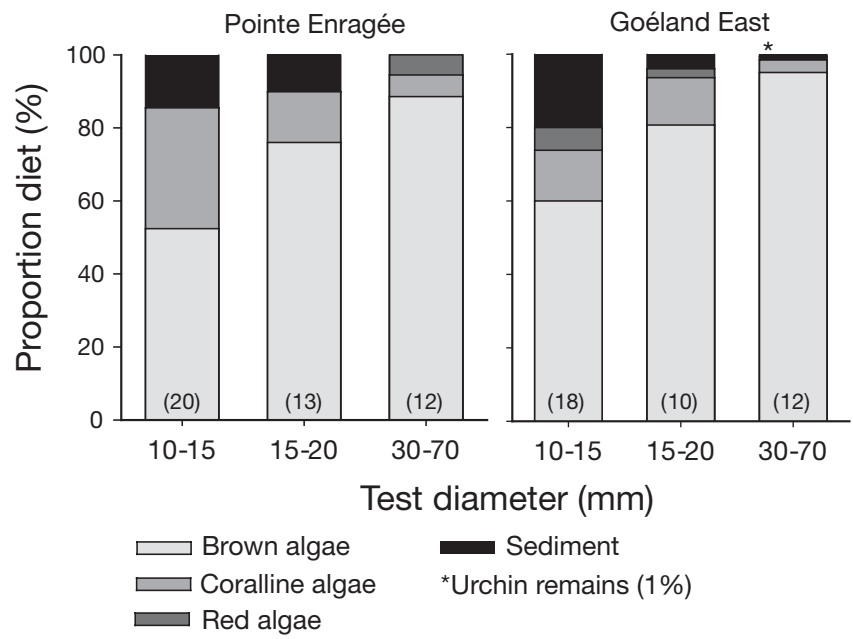

Fig. 10. Strongylocentrotus droebachiensis. Relative proportions of different food items in the digestive tracts of 3 size groups of sea urchins at Pointe Enragée and Goéland East.

Number of urchins examined is indicated in parentheses

cus is similar to Strongylocentrotus droebachiensis, as Andrew \& Stocker (1986) found that individuals moved 0.2 to $0.7 \mathrm{~m} \mathrm{~d}^{-1}$ on a flat sediment bottom where there were patches of the macroalgae Ecklonia sp. and this compared to 0.8 to $1.8 \mathrm{~m} \mathrm{~d}^{-1}$ on a flat bottom with only coralline algae. In contrast, Tertschnig (1989) observed that the tropical urchin Tripneustes ventricosus moved more in a seagrass bed than on a reef without seagrass. The more rapid movement in the seagrass bed appeared to be because of greater predation risk from the conchs in the seagrass habitat. Thus, the movement of several echinoids appears to increase with decreasing food availability. One hypothesis for this pattern is that echinoids move more to search for food

Table 4. Reported movement of echinoids in natural habitats

\begin{tabular}{|c|c|c|c|c|c|}
\hline Species & Habitat & $\begin{array}{c}\text { Daily } \\
\text { movement (m) }\end{array}$ & $\begin{array}{l}\text { Directional } \\
\text { movement }\end{array}$ & Tagging technique & Study \\
\hline $\begin{array}{l}\text { Strongylocentrotus } \\
\text { droebachiensis }\end{array}$ & $\begin{array}{l}\text { Not specified } \\
\text { Barrens } \\
\text { Near Alaria fringe } \\
\text { Barrens }\end{array}$ & $\begin{array}{c}0.5 \\
\text { Mean }<2, \max .3 \\
0.4-0.7 \\
0.8-1.7\end{array}$ & $\begin{array}{c}- \\
- \\
\text { None } \\
\text { None }\end{array}$ & $\begin{array}{l}\text { Plastic tag through test } \\
\text { Not specified } \\
\text { Beads attached on a spine } \\
\text { Beads attached on a spine }\end{array}$ & $\begin{array}{l}\text { Propp (1977) } \\
\text { Garnick (1978) } \\
\text { Present study } \\
\text { Present study }\end{array}$ \\
\hline $\begin{array}{l}\text { Strongylocentrotus } \\
\text { franciscanus }\end{array}$ & $\begin{array}{l}\text { Kelp bed } \\
\text { Barrens }\end{array}$ & $\begin{array}{l}0.08-0.14 \\
0.50-0.54\end{array}$ & $\begin{array}{l}\text { None } \\
\text { None }\end{array}$ & $\begin{array}{l}\text { Straw over } \\
\text { a spine }\end{array}$ & $\begin{array}{l}\text { Mattisson et } \\
\text { al. (1977) }\end{array}$ \\
\hline $\begin{array}{l}\text { Evechinus } \\
\text { chloroticus }\end{array}$ & $\begin{array}{l}\text { Near Ecklonia fringe } \\
\text { Barrens }\end{array}$ & $\begin{array}{l}0.2-0.7 \\
0.8-1.8\end{array}$ & $\begin{array}{l}\text { None } \\
\text { None }\end{array}$ & $\begin{array}{l}\text { Plastic tubes } \\
\text { over several spines }\end{array}$ & $\begin{array}{l}\text { Andrew \& Stocker } \\
\text { (1986) }\end{array}$ \\
\hline $\begin{array}{l}\text { Paracentrotus } \\
\text { lividus }\end{array}$ & $\begin{array}{l}\text { Posidonia bed } \\
\text { Rocky substrate }\end{array}$ & $\begin{array}{l}0.38 \\
0.54\end{array}$ & $\begin{array}{l}\text { None } \\
\text { None }\end{array}$ & $\begin{array}{l}\text { Plastic tubes over several } \\
\text { spines or an elastic band }\end{array}$ & $\begin{array}{l}\text { Dance } \\
(1987)\end{array}$ \\
\hline $\begin{array}{l}\text { Tripneustes } \\
\text { ventricosus }\end{array}$ & $\begin{array}{l}\text { Seagrass bed } \\
\text { Patch reef }\end{array}$ & $\begin{array}{l}8.8 \\
3.7\end{array}$ & $\begin{array}{l}\text { None } \\
\text { None }\end{array}$ & $\begin{array}{l}\text { Marker placed } \\
\text { next to urchins }\end{array}$ & $\begin{array}{l}\text { Terstchnig } \\
\text { (1989) }\end{array}$ \\
\hline
\end{tabular}


in food-poor habitats (e.g. barrens). However, a confounding factor is urchin density. The reduced movement in food-rich habitats could be because movement is limited by encounters with conspecifics. Under high densities, urchins may have to spend time waiting for feeding opportunities, or for the dislodgement of conspecifics.

Urchin movement also appears to be inversely related to current velocity. At sites with strong current, where maximum current velocities ranged from 0.4 to $0.8 \mathrm{~m} \mathrm{~s}^{-1}$, urchins tended to move shorter distances than urchins at sites where the current velocity was $<0.3 \mathrm{~m} \mathrm{~s}^{-1}$. In the laboratory, Kawamata (1998) observed that the rate of movement of Strongylocentrotus nudus decreased with increasing current velocity with an abrupt decrease beginning at $0.3 \mathrm{~m} \mathrm{~s}^{-1}$ (he also observed that feeding rate decreased with velocity). Our results are consistent with this study, but as other factors (e.g. food proximity, urchin density, substratum heterogeneity and temperature) also varied among sites, we could not specifically identify the effect of current. Several earlier studies have shown that $S$. droebachiensis can often be dislodged by wave-induced algal movement near the lower limit of the kelp zone, particularly during storms (Keats 1991, Scheibling 1999, Siddon \& Witman 2003, Gagnon et al. 2004).

We also show that the rate of movement of urchins is not only determined by environmental factors in the habitat, but also by the conditions to which they have been exposed previously. Thus, urchins transplanted from the kelp bed to the barrens moved less than urchins taken from the barrens and returned to the barrens (Fig. 6). In contrast, similar transplant experiments with other echinoids did not show any effect of the habitat of origin (Tertschnig 1989, Yusa \& Yamamoto 1994). As several studies report that the nutritional state of $S$. droebachiensis influences its feeding rate (Minor \& Scheibling 1997, Meidel \& Scheibling 1999), nutritional state may also affect movement. However, this was not supported by our observations of urchins that were either fed or starved for $6 \mathrm{wk}$ and then released on the barrens. The 2 groups moved to a similar degree. Also, we found that the gut fullness of the released fed and starved urchins became similar to that of field specimens within $48 \mathrm{~h}$ (the starved urchins doubled their gut contents over this period, Fig. 8). Previous studies of effects of nutritional state on movement of different echinoid species provide contrasting results. Starved Lytechinus variegatus (Klinger \& Lawrence 1985) were observed to move less than fed individuals (but rates were similar for individuals starved for 2 and 4 wk), whereas starved Evechinus chloroticus (Dix 1970) and Echinometra mathaei (Hart \& Chia 1990) were found to move more than fed individuals.
We documented an increase in net distance displaced with increasing urchin size, as there was a significant increase between $10-15 \mathrm{~mm}$ and $15-20 \mathrm{~mm}$ urchins. We further recorded a much greater movement for $25-70 \mathrm{~mm}$ urchins, although the tagging technique was different. However, the rate of movement appears to stabilize after $25 \mathrm{~mm}$ as movement was not correlated with size for urchins measuring 25 to $70 \mathrm{~mm}$ in diameter. Interestingly, much of this increase appears to be explained by body dimensions, as the increase is much less when net distance displaced is divided by body diameter. This suggests that a similar effort to move for urchins $>10 \mathrm{~mm}$. Nevertheless, the absolute distance moved by 10-20 mm urchins restrict their access to food compared to $>25 \mathrm{~mm}$ urchins and the latter larger can cover considerable distances when conditions stimulate them to do so. Our previous documentation of the dispersal of calceintagged Strongylocentrotus droebachiensis (Dumont et al. 2004a) further demonstrated an abrupt change in mobility with increasing size. The same study showed that large juveniles $(10-15 \mathrm{~mm})$ had moved up to $0.5 \mathrm{~m}$ in $9 \mathrm{~d}$, which is consistent with the mean net distance of 0.64 (SE $=0.08) \mathrm{m}$ in $10 \mathrm{~d}$ for large juveniles in the present study. Thus, there is a reasonable agreement in the movement recorded using the 2 very different techniques.

Associated with the change in movement with size is a shift from being relatively sedentary and cryptic to being exposed on open surfaces. The majority of small juveniles ( $81 \%$ of tagged individuals) were found either hidden in crevices or covered with pieces of coralline algae, in contrast to only $8 \%$ of large adult urchins $(>25 \mathrm{~mm})$. In parallel, there was increased feeding on macroalgae (Fig. 10). The increased ingestion of macroalgae should increase the energy available for somatic and gonadal growth (Himmelman \& Nédélec 1990, Scheibling \& Anthony 2001). A similar change in diet between juveniles and adults occurs in other echinoids (Lawrence \& Lane 1982). Thus, the change in behaviour with increasing size appears to result in increased movement on open areas and increased ingestion of macroalgae. As $15 \mathrm{~mm}$ is also the size when Strongylocentrotus droebachiensis begins to reproduce, the behavioural change may be necessary to obtain additional energy for gonad growth. The change in foraging behaviour may contribute to the bimodal size-frequency distributions found in several echinoid species (Tegner \& Dayton 1981, Andrew \& Choat 1982, Scheibling \& Hamm 1991). Juvenile urchins adopt a cryptic behaviour that may serve as a defensive strategy against predators but upon attaining a size where they are less vulnerable to predators, they actively move about in search of food resources. Surprisingly, at $15 \mathrm{~mm}, S$. droe- 
bachiensis have not attained a size refuge from predators such as lobsters, crabs and fish (Scheibling \& Hamm 1991). This would suggest there is a compromise between avoiding predators and the need to forage in open areas to support production of gametes.

Several workers hypothesize that migration explains the difference in the size structure of Strongylocentrotus droebachiensis between barrens and kelp bed habitats (Propp 1977, Meidel \& Scheibling 1998, Scheibling et al. 1999, Vadas et al. 2002). Since urchins on barrens can move up to $5 \mathrm{~m}$ per day, and $11 \mathrm{~m}$ in $3 \mathrm{~d}$, they should easily be able to cover the distance between barrens and shallow water kelp beds. Movement rates may also change seasonally. For example, Konar (2001) observed that the movement of S. polyacanthus towards pieces of algae placed in a barrens habitat was more rapid in the summer than in the winter (although low movement was observed throughout the year in a kelp bed habitat). The high densities of urchins just below the kelp zone may in itself reduce the ability of urchins from deeper water to reach this zone. However, our short-term tagging trials did not reveal any directional movement of urchins, and most individuals reversed direction daily (Figs. $3 \& 4$ ). Although chemodetection over short distances is widely known in echinoderms (Sloan \& Campbell 1982), our tagging trials suggest that urchins on barrens are not drawn toward kelp beds located $>10 \mathrm{~m}$ away. Dix (1970) observed that over several months only a few tagged Evechinus chloroticus moved between rocky subtidal sites separated by $<5 \mathrm{~m}$ (however, in his study the urchins were probably stressed because the tagging procedure involved perforating the test). Although urchins show a difference in foraging activity between the barrens and kelp beds, no studies (including ours) have reported the movement of identified individuals from barrens to kelp beds or have documented movement oriented towards kelp beds. Interestingly, however, directional movement on vertical walls has been reported for 3 echinoids, Paracentrotus lividus, Arbacia lixula (Chelazzi et al. 1997) and Anthocidaris crassispina (Freeman 2003), following transplantation from greater or lesser depths. These authors suggested that the urchins returned to their initial water depth to prevent the dislodgement by wave surge.

Post-settlement movement can contribute to the recovery of disturbed areas. Several sea urchin removal studies have documented the immigration of large urchins; indeed, several workers needed to make frequent visits to maintain experimental sites free of urchins (Himmelman et al. 1983, Keats et al. 1990, Leinaas \& Christie 1996). Such local movements should result in rapid repopulation of areas where densities have been reduced, for example as when urchins are killed by ice scour (Keats 1991, Dumont et al. 2004b). In contrast, recolonization following complete mortalities over large areas, as caused by pathogens (Lessios 1988, Scheibling \& Raymond 1990) or abiotic factors (Lawrence 1996), will require longer periods because recruitment will depend completely on larval settlement.

Acknowledgements. We are grateful to C. Bégin, D. Aiello, I. Deschênes, A. Drouin, S.-P. Gingras, P. Grondin, M.-O. Nadon, F. Praira, M. Thompson, C. Vallières and G. Wagner for their extensive help during field and laboratory work. Special thanks to D. Drolet for many discussions to improve the tagging technique and the manuscript. Thanks also to L. Johnson, who provided helpful comments on the manuscript, D. Levitan, and 2 anonymous reviewers. This study was funded by NSERC and FCAR grants to J.H.H. and financial support was provided to C.P.D. by Québec-Océan and the Biology Department of Université Laval. M.P.R. received support from the Biology Department at Villanova.

\section{LITERATURE CITED}

Agatsuma Y, Nakata A, Matsuyama K (2000) Seasonal foraging activity of the sea urchin Strongylocentrotus nudus on coralline flats in Oshoro Bay in south-western Hokkaido, Japan. Fish Sci 66:198-203

Andrew NL (1993) Spatial heterogeneity, sea urchin grazing, and habitat structure on reefs in temperate Australia. Ecology 74:292-302

Andrew NL, Choat JH (1982) The influence of predation and conspecific adults on the abundance of juvenile Evechinus chloroticus (Echinoidea: Echinometridae). Oecologia 54: 80-87

Andrew NL, Stocker LJ (1986) Dispersion and phagokinesis in the echinoid Evechinus chloroticus (Val.). J Exp Mar Biol Ecol 100:11-23

Batschelet E (1981) Circular statistic in biology. Academic Press, New York

Bernstein BB, Williams BE, Mann KH (1981) The role of behavioral responses to predators in modifying urchins (Strongylocentrotus droebachiensis) destructive grazing and seasonal foraging patterns. Mar Biol 63:39-49

Bernstein BB, Schroeter S, Mann KH (1983) Sea urchin (Strongylocentrotus droebachiensis) aggregating behavior investigated by a subtidal multifactorial experiment. Can J Fish Aquat Sci 40:1975-1986

Carpenter RC (1984) Predator and population density control of homing behavior in the Caribbean echinoid Diadema antillarum Phillippi. Mar Biol 82:101-108

Chapman ARO (1981) Stability of sea urchin dominated barren grounds following destructive grazing of kelp in St. Margaret's bay, eastern Canada. Mar Biol 62:307-311

Chapman MG (1986) Assessment of some controls in experimental transplants of intertidal gastropods. J Exp Mar Biol Ecol 103:181-201

Chelazzi G, Serra G, Bucciarelli G (1997) Zonal recovery after experimental displacement in two sea urchins co-occurring in the Mediterranean. J Exp Mar Biol Ecol 212:1-7

Dance C (1987) Patterns of activity of the sea urchin Paracentrotus lividus in the Bay of Port-Cros (Var, France, Mediterranean). PSZN I: Mar Ecol 8:131-142

Dix TG (1970) Biology of Evechinus chloroticus (Echiniodea: 
Echinometridae) from different localities: 2. Movement. NZ J Mar Fresh Res 4:267-277

Duggan RE, Miller RJ (2001) External and internal tags for the green sea urchin. J Exp Mar Biol Ecol 258:115-122

Dumont CP, Himmelman JH, Russell MP (2004a) Size-specific movement of green sea urchins Strongylocentrotus droebachiensis on urchin barrens in eastern Canada. Mar Ecol Prog Ser 276:93-101

Dumont CP, Himmelman JH, Russell MP (2004b) Sea urchin mortality associated with algal debris from ice scour. In: Heinzeller T, Nebelsick JH (eds) 11th International Echinoderm Conference Proceedings. Balkema, Rotterdam, p $177-182$

Ebeling AW, Laur DR, Rowley RJ (1985) Severe storm disturbances and reversal of community structure in a southern California kelp forest. Mar Biol 84:287-294

Freeman SM (2003) Size-dependent distribution, abundance and diurnal rhythmicity patterns in the short-spined sea urchin Anthocidaris crassispina. Estuar Coast Shelf Sci 58: 703-713

Gagnon P, Himmelman JH, Johnson LE (2004) Temporal variation in community interfaces: kelp bed boundary dynamics adjacent to persistent urchin barrens. Mar Biol 144: 1191-1203

Garnick E (1978) Behavioral ecology of Strongylocentrotus droebachiensis (Müller) (Echinodermata: Echinoidea). Aggregating behaviour and chemotaxis. Oecologia 37: $77-84$

Grünbaum H, Bergman G, Abbott DP, Ogden JC (1978) Intraspecific agonistic behavior in the rock-boring sea urchin Echinometra lucunter (L.) (Echinodermata: Echinodea). Bull Mar Sci 28:181-188

Hagen NT (1996) Tagging sea urchins: a new technique for individual identification. Aquaculture 139:271-284

Hagen NT, Mann KH (1992) Functional response of the predators American lobster Homarus americanus (Milne-Edwards) and Atlantic wolfish Anarhichas lupus (L.) to increasing numbers of the green sea urchin Strongylocentrotus droebachiensis (Müller). J Exp Mar Biol Ecol 159:89-112

Hagen NT, Mann KH (1994) Experimental analysis of factors influencing the aggregating behavior of the green sea urchin Strongylocentrotus droebachiensis (Müller). J Exp Mar Biol Ecol 176:107-126

Hagen NT, Anderson A, Stabell OB (2002) Alarm responses of the green sea urchin, Strongylocentrotus droebachiensis, induced by chemically labelled durophagous predators and simulated acts of predation. Mar Biol 140:365-374

Harrold C, Reed DC (1985) Food availability, sea urchin grazing, and kelp forest community structure. Ecology 66: 1160-1169

Hart LJ, Chia FS (1990) Effect of food supply and body size on the foraging behaviour of the burrowing sea urchin Echinometra mathei (de Blainville). J Exp Mar Biol Ecol 135: 99-108

Himmelman JH (1984) Urchin feeding and macroalgal distribution in Newfoundland, eastern Canada. Nat Can 111: $337-348$

Himmelman J (1986) Population biology of green sea urchins on rocky barrens. Mar Ecol Prog Ser 33:295-306

Himmelman J, Nédélec H (1990) Urchin foraging and algal survival strategies in intensely grazed communities in eastern Canada. Can J Fish Aquat Sci 47:1011-1026

Himmelman JH, Cardinal A, Bourget E (1983) Community development following removal of urchins, Strongylocentrotus droebachiensis, from the rocky subtidal zone of the St. Lawrence estuary, eastern Canada. Oecologia 59: $27-39$
Jensen M (1966) The response of two sea-urchins to the seastar Marthasterias glacialis (L.) and other stimuli. Ophelia 3:209-219.

Johnson CR, Mann KH (1982) Adaptations of Strongylocentrotus droebacheinsis for survival on barren grounds in Nova Scotia. In: Lawrence JM (ed) International Echinoderms Conference. Balkema, Tampa Bay, FL, p 277-283

Jones GP, Andrew NL (1990) Herbivory and patch dynamics on rocky reefs in temperate Australasia: the roles of fish and sea urchins. Aust J Ecol 15:505-520

Kawamata S (1998) Effect of wave-induced oscillatory flow on grazing by a subtidal sea urchin Strongylocentrotus nudus (A. Agassiz). J Exp Mar Biol Ecol 224:31-48

Keats DW (1991) Refugial Laminaria abundance and reduction in urchin grazing in communities in the North-West Atlantic. J Mar Biol Assoc UK 71 867-876

Keats DW, South GR, Steele DH (1985) Ecology of juvenile green sea urchins (Strongylocentrotus droebachiensis) at an urchin dominated sublittoral site in eastern Newfoundland. In: Keegan BF, O'Connoer BCS (eds) Echinodermata. Balkema, Rotterdam, p 295-302

Keats DW, South GR, Steele DH (1990) Effects of an experimental reduction in grazing by sea urchins on a benthic macroalgal community in eastern Newfoundland. Mar Ecol Prog Ser 68:181-193

Klinger TS, Lawrence JM (1985) Distance perception of food and the effect of food quantity on feeding behavior of Lytechinus variegatus (Lamarck) (Echinodermata: Echinoidea). Mar Behav Physiol 11:327-344

Konar B (2000) Seasonal inhibitory effects of marine plants on sea urchins: structuring communities the algal way. Oecologia 125:208-217

Konar B (2001) Seasonal changes in subartic sea urchin populations from different habitats. Polar Biol 24:754-763

Konar B, Estes JA (2003) The stability of boundary regions between kelp beds and deforested areas. Ecology 84: 174-185

Lawrence JM (1996) Mass mortality of echinoderms from abiotic factors. Echinoderm Studies 5:101-137

Lawrence JM, Lane JM (1982) The utilization of nutrients by postmetamorphic echinoderms. In: Jangoux M, Lawrence JM (eds) Echinoderm nutrition. Balkema, Rotterdam, p 331-372

Leinaas HP, Christie H (1996) Effects of removing sea urchins (Strongylocentrotus droebachiensis): stability of the barren state and succession of kelp forest recovery in the east Atlantic. Oecologia 105:524-536

Lessios HA (1988) Mass mortality of Diadema antillarum in the Caribbean: what we have learned? Annu Rev Ecol Syst 19:371-393

Lissner AL (1980) Some effects of tuburlence on the activity of the sea urchin Centrostephanus coronatus Verrill. Mar Biol 48:185-193

Lubchenco J, Gaines SD (1981) A unified approach to marineplant herbivore interactions. I. Populations and communities. Annu Rev Ecol Syst 12:405-437

Mann KH (1985) Invertebrate behaviour and the stucture of marine benthic communities. In: Sibly RM, Smith RH (eds) Behavioural ecology. Ecological consequences of adaptative behaviour. Blackwell Scientific Publ, Oxford, p 227-246

Mann KH, Wright JLC, Welsford BE, Hatfield E (1984) Responses of the sea urchin Strongylocentrotus droebachiensis (O.F. Müller) to water-borne stimuli from potential predators and potential food algae. J Exp Mar Biol Ecol 79:233-244

Mattisson JE, Trent JD, Shanks AL, Akin TB, Pearse JS (1977) Movement and feeding activity of red sea urchins 
(Strongylocentrotus franciscanus) adjacent to a kelp forest. Mar Biol 39:25-30

Meidel SK, Scheibling RE (1998) Size and structure of the sea urchin Strongylocentrotus droebachiensis in different habitats. In: Mooi R, Telford M (eds) Echinoderms: San Francisco. Balkema, Rotterdam, p 737-742

Meidel SK, Scheibling RE (1999) Effects of food type and ration on reproductive maturation and growth of the sea urchin Strongylocentrotus droebachiensis. Mar Biol 134: 155-166

Menge BA (1995) Indirect effects in marine rocky intertidal interaction webs: patterns and importance. Ecol Monogr 65:21-74

Minor MA, Scheibling RE (1997) Effects of food ration and feeding regime on growth and reproduction of the sea urchin Strongylocentrotus droebachiensis. Mar Biol 129: 159-167

Nelson BV, Vance RR (1979) Diel foraging patterns of the sea urchin Centrostephanus coronatus as a predator avoidance strategy. Mar Biol 51:251-258

Propp MV (1977) Ecology of the sea urchin Strongylocentrotus droebachiensis of the Barrents Sea: metabolism and regulation of abundance. Sov J Mar Biol 3:27-37

Raymond BG, Scheibling RE (1987) Recruitment and growth of the sea urchin Strongylocentrotus droebachiensis (Müller) following mass mortalities off Nova Scotia, Canada. J Exp Mar Biol Ecol 108:31-54

Rodriguez SR, Farina JM (2001) Effect of drift kelp on the spatial distribution pattern of the sea urchin Tetrapygus niger: a geostatistical approach. J Mar Biol Assoc UK 81:179-180

Rogers CN, Williamson JE, Carson DG, Steinberg PD (1998) Diel vertical movement by mesograzers on seaweeds. Mar Ecol Prog Ser 166:301-306

Scheibling RE, Anthony SX (2001) Feeding, growth and reproduction of sea urchins (Strongylocentrotus droebachiensis) on single and mixed diets of kelp (Laminaria spp.) and the invasive alga Codium fragile ssp. Tomentosoides. Mar Biol 139:139-146

Scheibling RE, Hamm J (1991) Interactions between sea urchins (Strongylocentrotus droebachiensis) and their predators in field and laboratory experiments. Mar Biol 110:105-116

Scheibling RE, Raymond BG (1990) Community dynamics on a subtidal cobble bed following mass mortalities of sea urchins. Mar Ecol Prog Ser 63:127-145

Scheibling RE, Hennigar AW, Balch T (1999) Destructive grazing, epiphytism, and disease: the dynamics of sea

Editorial responsibility: Don Levitan (Contributing Editor), Tallahassee, Florida, USA urchin - kelp interactions in Nova Scotia. Can J Fish Aquat Sci 56:2300-2314

Shulman MJ (1990) Aggression among sea urchins on Caribbean coral reefs. J Exp Mar Biol Ecol 140:197-207

Siddon CE, Witman JD (2003) Influence of chronic, low-level hydrodynamic forces on subtidal community structure. Mar Ecol Prog Ser 261:69-110

Sloan NA, Campbell AC (1982) Perception of food. In: Jangoux $M$, Lawrence JM (eds) Echinoderm nutrition. Balkema, Rotterdam, p 3-24

Tegner MJ, Dayton PK (1981) Population structure, recruitment and mortality of two sea urchins (Strongylocentrotus franciscanus and $S$. purpuratus) in a kelp forest. Mar Ecol Prog Ser 5:255-268

Tertschnig WP (1989) Diel activity patterns and foraging dynamics of the sea urchin Tripneustes ventricosus in a tropical seagrass community and a reef environment (Virgin Islands). PSZN I: Mar Ecol 10:3-21

Tilman D, Kareiva P (1997) Spatial ecology: the role of space in population dynamics and interpsecific interactions. Princeton University Press, Princeton, NJ

Turchin P (1998) Quantitative analysis of movement: measuring and modeling population redistribution in animals and plants. Sinauer Associates, Sunderland, MA

Tusuchiya M, Nishihira M (1985) Agonistic behavior and its effect on the dispersion pattern intwo types of the sea urchin, Echinometra mathaei (Blainville). Galaxea 4: 37-48

Tuya F, Martin JA, Luque A (2004) Patterns of nocturnal movement of the long-spined sea urchin Diadema antillarum (Philippi) in Gran Canaria (the Canary Islands, central East Atlantic Ocean). Helgol Mar Res 58:26-31

Underwood AJ (1997) Experiments in ecology: their logical design and interpretation using analysis of variance. Cambridge University Press, Cambridge, p 504

Vadas RL, Smith BD, Beal B, Dowling T (2002) Sympatric growth morphs and size bimodality in the green sea urchin (Strongylocentrotus droebachiensis). Ecol Monogr 72:113-132

Werner EE, Gilliam JF (1984) The ontogenetic niche and species interactions in size-structured populations. Annu Rev Ecol Syst 15:393-425

Yusa Y, Yamamoto T (1994) Inside or outside the pits: variable mobility in conspecific sea urchin, Anthocidaris crassispina (A. Agassiz). Publ Seto Mar Biol Lab 36:255-266

Zar JH (1999) Biostatistical analysis. Prentice-Hall, Englewood Cliffs, NJ

Submitted: October 5, 2004; Accepted: November 30, 2005 Proofs received from author(s): July 1, 2006 